\title{
Selectivity of Glyphosate in Tank MiXtuRes fOR RR SOybean IN Sequential Applications with Mixtures only in the First or Second Application ${ }^{1}$
}

\author{
Seletividade de Glyphosate em Misturas em Tanque para Soja RR em Aplicações Sequenciais \\ com Mistura Apenas na Primeira ou na Segunda Aplicação
}
ALONSO, D.G. ., ${ }^{2,}$, CONSTANTIN, J. ${ }^{3,7}$, OLIVEIRA JR., R.S..$^{3,7}$, BIFFE, D.F. ${ }^{2,8}$, RAIMONDI, M.A. ${ }^{2,7}$, GEMELLI, A. ${ }^{4,7}$, BLAINSKI, E. ${ }^{5,7}$ and CARNEIRO, J.C. ${ }^{6}$,

\begin{abstract}
Tank mixtures among herbicides of different action mechanisms might increase weed control spectrum and may be an important strategy for preventing the development of resistance in RR soybean. However, little is known about the effects of these herbicide combinations on soybean plants. Hence, two experiments were carried out aiming at evaluating the selectivity of glyphosate mixtures with other active ingredients applied in postemergence to RR soybean. The first application was carried out at V1 to V2 soybean stage and the second at V3 to V4 (15 days after the first one). For experiment I, treatments (rates in $\mathrm{g} \mathrm{ha}^{-1}$ ) evaluated were composed by two sequential applications: the first one with glyphosate (720) in tank mixtures with cloransulam (30.24), fomesafen (125), lactofen (72), chlorimuron (12.5), flumiclorac (30), bentazon (480) and imazethapyr (80); the second application consisted of isolated glyphosate (480). In experiment II, treatments also consisted of two sequential applications, but tank mixtures as described above were applied as the second application. The first one in this experiment consisted of isolated glyphosate (720). For both experiments, sequential applications of glyphosate alone at 720/480, 960/480, 1200/480 and 960/720 (Expt. I) or 720/480, 720/720, 720/960 and 720/1200 (Expt. II) were used as control treatments. Applications of glyphosate tank mixtures with other herbicides are more selective to RR soybean when applied at younger stages whereas applications at later stages might cause yield losses, especially when glyphosate is mixed with lactofen and bentazon.
\end{abstract}

Keywords: herbicides, glyphosate-resistant soybean, tolerance, injury.

\begin{abstract}
RESUMO - A mistura em tanque entre herbicidas de diferentes mecanismos de ação pode aumentar o espectro de controle dos tratamentos e consistir de uma nova estratégia de controle de plantas daninhas na cultura da soja RR. No entanto, pouco se sabe sobre os efeitos destas misturas nas plantas de soja. Dessa forma, foram realizados dois experimentos com o objetivo de avaliar a seletividade do glyphosate isolado ou em misturas com outros princípios ativos aplicados em pósemergência à soja RR. Nos experimentos I e II os tratamentos foram constituídos por aplicações seqüenciais de herbicidas, sendo a primeira realizada no estádio V1 a V2 da soja e a segunda no estádio V3 a V4 (15 dias após a primeira). Para o experimento I, os tratamentos testados (doses em $\mathrm{g} \mathrm{ha}^{1}$ ) foram compostos por duas aplicações sequenciais: a primeira com glyphosate (720) em mistura em tanque com cloransulam (30.24), fomesafen (125), lactofen (72), chlorimuron (12.5), flumiclorac (30), bentazon (480) e imazethapyr (80); a segunda aplicação consistiu de glyphosate (480) isolado. No segundo experimento, os tratamentos também foram compostos por duas aplicações
\end{abstract}

1 Recebido para publicação em 28.11.2009 e na forma revisada em 12.11.2010.

Parte da dissertação do primeiro autor apresentada ao Programa de Pós-Graduação em Agronomia da Universidade Estadual de Maringá para obtenção do título de Mestre em Agronomia, área de concentração em Proteção de Plantas.

2 Engo-Agr ${ }^{-0}$., M.Sc., Doutorando em Agronomia pela Universidade Estadual de Maringá - UEM na área de Proteção de Plantas (NAPD/UEM), Dep. de Agronomia, Av. Colombo, 5790, 87020-900, Maringá-PR, <alonsodg07@hotmail.com>; ${ }^{3}$ Professor Associado, Núcleo de Estudos Avançados em Ciência das Plantas Daninhas (NAPD/UEM), Dep. de Agronomia, UEM; ${ }^{4}$ Graduando em Agronomia (NAPD/UEM), Bolsista de Iniciação Cientifica; ${ }^{5}$ Eng $^{-}$-Agr ${ }^{\circ}$., Mestrando do Programa de Pós-Graduação em Agronomia na área de Proteção de Plantas (NAPD/UEM); ${ }^{6}$ Engo-Agr ${ }^{\circ}$., M.Sc., (NAPD/UEM); ${ }^{7}$ Bolsistas do CNPq; ${ }^{8}$ Bolsista da Capes.

Planta Daninha, Viçosa-MG, v. 28, n. 4, p. 865-875, 2010 
seqüenciais, mas as misturas em tanque descritas anteriormente foram aplicadas na segunda aplicação, sendo a primeira composta de glyphosate (720) isolado. Ambos experimentos foram compostos ainda por aplicações seqüenciais de glyphosate isolado nas doses 720/480, 960/480, 1200/480 e 960/ 720 (Experimento I) ou 720/480, 720/720, 720/960 e 720/1200 (Experimento II) como testemunhas. Aplicações de misturas de glyphosate com outros herbicidas apresentam maior seletividade para soja RR quando aplicadas em estádios mais novos, enquanto que aplicações das misturas em estádios mais tardios podem provocar perdas de produtividade, especialmente quando glyphosate é misturado à lactofen e bentazon.

Palavras-chave: herbicidas, soja resistente ao glyphosate, tolerância, injúrias

\section{INTRODUCTION}

Weed interference may cause significant yield losses to soybean (Glycine max) due to competition for resources which are essential for its development. Weed control is, therefore, essential during crop development. Adequate control is even more relevant in the initial period of crop cycle, since soybean establishment under clean conditions improves its capacity to prevent further weed interference later in crop cycle.

Weed interference during glyphosateresistant transgenic soybean ( $R R$ soybean) cycle decreased grain yield in $73 \%$ for low infestation, and $92.5 \%$ for high infestation areas. The maximum period that crop was able to tolerate weed infestation without yield decrease was 17 and 11 days for low and high infestation respectively (Silva et al., 2009).

With the development of RR soybean, postemergence weed control, which was exclusively carried out with herbicides selective to the crop, became a new option. The introduction of such technology in the market boosted glyphosate use. However, the possibility of using only one herbicide to control weeds both at burndown and postemergence may result in tolerant or resistant biotypes selection, consequently providing unsatisfactory control. Weeds such as Synedrellopsis grisebachii, Spermacoce latifolia, Commelina benghalensis, and Tridax procumbens have been selected due to successive glyphosate applications in the Brazilian savanna (Procópio et al., 2007).

One of the main alternatives to prevent the appearance, or to obtain good control of such biotypes, is to use herbicides of different action mechanisms in tank mixtures (Lich et al., 1997). Herbicide combinations are beneficial once they require less time for application and cost less compared to the application of a single herbicide, and they may also increase the spectrum of controlled weeds (Norris et al., 2001).

Nevertheless, it is difficult to predict which mixtures will not cause visual injuries to several cultivars of genetically modified soybean commercialized in Brazil; since it is commonly known that plant tolerance to a certain herbicide, besides its inherent characteristics, is also directly associated to other factors, such as environmental conditions, and the characteristics of herbicides and spraying suspension.

Hence, it is very important to study the selectivity of glyphosate isolated or in mixtures not only taking phytointoxication effects into account, but mainly the effect in crop yield, once there are reports on the recovery of visual phytotoxic effects caused by herbicides.

Therefore, two experiments were carried out in order to evaluate the selectivity of glyphosate, whether isolated or mixed with other herbicides in sequential applications for glyphosate-resistant soybean, cultivar CD 214 RR.

\section{MATERIAL AND METHODS}

Two experiments were conducted on a nontillage area at Nossa Senhora Aparecida Farm, Floraí, PR, (2316'19,73” S; 52 $23^{\circ} 04,30^{\prime \prime} \mathrm{W}$; altitude $=443 \mathrm{~m})$. The local climate is characterized as subtropical with summer showers and dry winter, Cfa, according to Wilhem Köeppen classification. 
The soil of the experimental area was identified as Rhodic Ferralsol with sandy texture, constituted of $36 \%$ coarse sand, $54 \%$ fine sand, $8 \%$ clay and $2 \%$ silt. Regarding its chemical analysis, on a sample taken from 0 to $20 \mathrm{~cm}$ of depth, the soil showed $5.7 \mathrm{pH}$ in $\mathrm{CaCl}_{2}$; $6.6 \mathrm{pH}$ in $\mathrm{H}_{2} \mathrm{O} ; 2.36 \mathrm{cmol}_{\mathrm{c}} \mathrm{dm}^{-3} \mathrm{H}^{+}+\mathrm{Al}^{3+}$; $2.18 \mathrm{cmol}_{\mathrm{c}} \mathrm{dm}^{-3} \mathrm{Ca}^{+2} ; 0.36 \mathrm{cmol}_{\mathrm{c}} \mathrm{dm}^{-3} \mathrm{Mg}^{+2}$; $0.13 \mathrm{cmol}_{\mathrm{c}} \mathrm{dm}^{-3} \mathrm{~K}^{+} ; 15.0 \mathrm{mg} \mathrm{dm}^{-3} \mathrm{P}$, and $4.35 \mathrm{~g} \mathrm{dm}^{-3} \mathrm{C}$.

The site had been cultivated with oats in the winter prior to soybean sowing. Oat had been burn down ten days before soybean was sown with 1.260 g a.e. ha ${ }^{1}$ glyphosate. During sowing, fertilization consisted of $270 \mathrm{~kg} \mathrm{ha}^{-1}$ of the 0-18-18 NPK formula and $83 \mathrm{~kg} \mathrm{ha}^{-1}$ of $\mathrm{KCl}$. Seeds were treated with fungicide $(35 \mathrm{~g}$ $\mathrm{kg}^{-1}$ Fludioxonil + $10 \mathrm{~g} \mathrm{~kg}^{-1}$ of Metalaxyl-M) at $0,001 \mathrm{~L} \mathrm{~kg}^{-1}$ of seeds and with insecticide (250 $\mathrm{g} \mathrm{L}^{-1}$ Fipronil) at $0,001 \mathrm{~L} \mathrm{~kg}^{-1}$ of seeds, and also with peat inoculant at the rate $2 \mathrm{~g} \mathrm{~kg}^{-1}$ of seeds. Forty days after germination, $83 \mathrm{~kg} \mathrm{ha}^{-1}$ of $\mathrm{KCl}$ were applied.

Sowing was carried out on 9.11.2006 with $0.45 \mathrm{~m}$ between lines and density of approximately 18 seeds $\mathrm{m}^{-1}$. The cultivar used in both experiments was CD $214 \mathrm{RR}$, an early maturation group cultivar. Harvest was done manually on 3.20.2007.

For both experiments, the experimental design was entirely randomized in split-plot scheme with twofold checks, and four replicates. The herbicides were the main factor studied in the plots, and the condition of herbicide presence or absence was studied in the subplots. The subplots were compounded of eight lines of sowing with $0.45 \mathrm{~m}$ apart and five meters long totalizing $18 \mathrm{~m}^{2}$ per subplot. The subplot area used for evaluations was made up of six lines, disregarding the first and final half meter of each subplot.

The twofold check technique was previously described by Fagliari et al. (2001) and was initially proposed for the evaluation of herbicide selectivity in sugarcane. More recently, it was also used to study herbicide selectivity in soybeans (Meschede et al., 2004; Jaremtchuk et al., 2008). This type of experiment offers more efficient local control, especially when compared to the traditional randomized block design with a single check per block (Meschede et al., 2004).
To prevent weed interference on soybeans, all subplots were kept free of weeds by manual hoeing throughout crop cycle.

For experiment I, treatments (rates in $\mathrm{g}$ ha $\left.{ }^{1}\right)$ evaluated were composed by two sequential applications: the first one with glyphosate (720) in tank mixtures with cloransulam (30.24), fomesafen (125), lactofen (72), chlorimuron (12.5), flumiclorac (30), bentazon (480) and imazethapyr (80); the second application consisted of isolated glyphosate (480). In experiment II, treatments also consisted of two sequential applications, but tank mixtures as described above were applied as the second application. The first one in this experiment consisted of isolated glyphosate (720). For both experiments, sequential applications of glyphosate alone at 720/480, 960/480, 1200/ 480 and 960/720 (Expt. I) or 720/480, 720/720, $720 / 960$ and 720/1200 (Expt. II) were used as control treatments.

A backpack sprayer operating under constant pressure $\left(2 \mathrm{kgf} \mathrm{cm}^{-2}\right)$ and equipped with XR-110.02 flat fan nozzles was used. Such application conditions promoted $200 \mathrm{~L} \mathrm{ha}^{-1}$ of spray volume. As for the climate, temperature was $31{ }^{\circ} \mathrm{C}$ and the relative humidity was $62 \%$ with wet soil and $2 \mathrm{~km} \mathrm{~h}^{-1}$ wind speed for the first sequential, and temperature of $33^{\circ} \mathrm{C}$ and relative humidity of $61 \%$ with wet soil and no wind for the second sequential of experiment I. For experiment II, climate conditions were the following: $26^{\circ} \mathrm{C}$ of temperature and $92 \%$ of relative humidity with wet soil and maximum of $4 \mathrm{~km} \mathrm{~h}^{-1}$ wind speed for the first sequential and $33.5^{\circ} \mathrm{C}$ of temperature and $67 \%$ relative humidity with wet soil and no wind for the second sequential.

Visual evaluations of phytointoxication, plant height, stand, and soil cover by crop canopy were carried out, and the number of pods per plant was counted. After harvest, the hundred grain mass and yield were evaluated.

For the visual phytointoxication evaluations, percentage marks were attributed to each experimental unit with herbicides (visual scale, $0-100 \%$ ) considering, in this case, visual symptoms on plants according to its development (SBCPD, 1995).

Visual evaluations of soil cover by crop canopy were carried out to determine the effect 
of treatments on the development of canopy and soil cover by plants. The scale used was the one of percentage marks from zero (no soil cover between crop lines) to $100 \%$ representing the complete soil cover by the crop.

The number of live plants was counted in three linear meters in two central lines of each subplot, and results were expressed as plants $\mathrm{m}^{-1}$.

To determine the average height, the height of 10 plants per subplot was measured. Plants were measured randomly inside the subplot area of each experimental unit. They were measured from the ground to the insertion of the last trifoliolate leaves completely expanded.

During harvesting, pods were counted in ten plants per plot, which were taken randomly from the subplot area obtaining the average per plant of each experimental unit. The hundred grain mass was obtained by counting and weighing three samples of one hundred grains per experimental unit. Three samples were taken per subplot to determine grain moisture. Data were corrected to $13 \%$ moisture.

Data were submitted to variance analysis using the $\mathrm{F}$ test, and the means were compared through the Tukey test at 5\% probability.

\section{RESULTS AND DISCUSSION}

\section{Experiment I}

After the first application (mixtures), visual symptoms of phytointoxication were more evident than after the second application, in which only glyphosate was applied to all treatments (Table 1).

All treatments caused injuries on soybean plants leading to visual symptoms of phytointoxication, which presented variable intensity and persistence for each treatment. Toxicity symptoms recovery from herbicide mixtures with glyphosate or isolated glyphosate for glyphosate-resistant soybean is reported by several authors such as Lich et al. (1997), Gonzini et al. (1999), Elmore et al. (2001), Grey \& Raymer (2002), Ellis \& Griffin (2003), Norsworthy (2004) and Procópio et al. (2007).

For glyphosate mixtures with PROTOX inhibitor herbicides, the effects observed were chlorotic stains progressing to necrosis and generalized distortion of those leaflets which received direct application. The most evident effects were caused by the mixture with lactofen. On the other hand, for mixtures with ALS inhibitor herbicides the one that contained chlorimuron caused more injuries to plants.

Table 1 - Mean soybean injury (visual scale, \%), cultivar CD 214 RR, submitted to different sequential treatments with glyphosate, whether isolated or mixed with other herbicides (Experiment I). Floraí, PR, 2006/2007

\begin{tabular}{|c|c|c|c|c|c|}
\hline \multirow{3}{*}{ Treatment } & \multirow{3}{*}{ Rate $\left(\mathrm{g} \mathrm{ha}^{-1}\right)^{1 /}$} & \multicolumn{4}{|c|}{ Soybean injury $(\%)$} \\
\hline & & \multicolumn{3}{|c|}{$1^{\text {st }}$ application } & \multirow{2}{*}{$\frac{2^{\text {nd }} \text { application }}{3 \text { DASA }}$} \\
\hline & & 3 DAA & 7 DAA & $15 \mathrm{DAA}$ & \\
\hline Gly+cloransulam/gly & $720+30.24 / 480$ & 55.0 & 38.8 & 16.3 & 16.3 \\
\hline Gly+fomesafen/gly & $720+125 / 480$ & 58.8 & 50.0 & 35.0 & 16.3 \\
\hline Gly+lactofen/gly & $720+72 / 480$ & 66.3 & 65.0 & 37.5 & 23.8 \\
\hline Gly+chlorimuron/gly & $720+12.5 / 480$ & 63.8 & 67.5 & 36.3 & 18.8 \\
\hline Gly+flumiclorac/gly & $720+30 / 480$ & 48.8 & 47.5 & 30.0 & 18.8 \\
\hline Gly+bentazon/gly & $720+480 / 480$ & 43.8 & 32.5 & 20.0 & 18.8 \\
\hline Gly+imazethapyr/gly & $720+80 / 480$ & 48.8 & 33.8 & 12.5 & 23.8 \\
\hline Gly/gly & $720 / 480$ & 27.5 & 22.5 & 7.5 & 15.0 \\
\hline Gly/gly & $960 / 480$ & 31.3 & 30.0 & 11.3 & 21.3 \\
\hline Gly/gly & $1200 / 480$ & 40.0 & 32.5 & 8.8 & 25.5 \\
\hline Gly/gly & $960 / 720$ & 35.0 & 25.0 & 8.8 & 21.3 \\
\hline
\end{tabular}

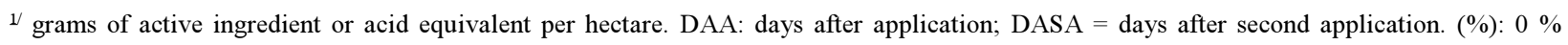

$=$ no injuries, $100 \%=$ plant death. Gly - Glyphosate. +: Herbicide tank mixtures. /: Sequential applications. 
Visual injuries started to diminish 7 days after the first application. After 15 days from the first application, young leaves still presented visual symptoms of phytointoxication in all treatments, which shows that mixture applications at early stages of soybean development result in longer effects of phytointoxication, possibly because plants are still too young when the application is carried out.

Although isolated glyphosate applications have caused phytointoxication to plants, they have always been similar or inferior to those caused by mixtures. Treatments consisting of glyphosate mixtures with PROTOX inhibitors or chlorimuron-ethyl caused leaf injuries superior to the other treatments at 7 and 15 days after the first application (DAA).

After the second application (isolated glyphosate) new symptoms are visible. However, they are less intense than those following mixture application. Phytointoxication evaluation results (\%) 15 days after the second application (DASA) are not shown, because no treatment presented visible symptoms on young trifoliolate leaves.

Treatments with isolated glyphosate as well as mixtures containing cloransulam, flumiclorac and bentazon did not differ significantly from their respective twofold checks; while mixtures with fomesafen, lactofen, chlorimuron, and imazethapyr presented significant reductions in canopy development at 3 DASA (Table 2). Reductions in soil cover by crop canopy, caused by these mixtures, are associated with leaf injuries, once such treatments promoted high levels of phytointoxication with necrosis at 7 DAA (Table 1).

At 15 DASA, it is possible to observe that there were no significant differences for any treatment, which shows that plants affected by treatments had already recovered (data not shown).

Mean values of soybean plant height for the experiment are shown in Table 3. Results of height evaluation at 15 DASA demonstrate that the only treatments which differ significantly from their checks for this variable were the ones containing mixtures of glyphosate with fomesafen or imazethapyr.
For height results at 90 DASA, it is possible to verify that soybean treated with mixtures of glyphosate with fomesafen or imazethapyr did not recover, remaining inferior to its respective checks. Treatments with mixtures of glyphosate with cloransulam-methyl or chlorimuron-ethyl also affected plant height significantly at 90 DASA. Such effects might be associated to growth depression promoted by ALS inhibitor herbicides (imazethapyr, cloransulam and chlorimuron), and also by glyphosate. Concerning fomesafen, the most prolonged effect on growth is possibly related to the level of injury caused by the treatment. Another possibility is that it may be related to the residual effect in the soil, which would promote longer outcome preventing the crop from recovering its full vegetative development. Ellis \& Griffin (2003) observed that treatments containing glyphosate (840 and $1.120 \mathrm{~g}^{\text {a.e. }} \mathrm{ha}^{-1}$ ), whether isolated or mixed with reduced rates of chlorimuron $(4.5$ and $6.7 \mathrm{~g} \mathrm{ha}^{-1}$ ), fomesafen (210 and $315 \mathrm{~g} \mathrm{ha}^{-1}$ ), and lactofen (112 and $168 \mathrm{~g} \mathrm{ha}^{-1}$ ) promoted injuries on soybean such as leaf chlorosis and reduction on plant height in all treatments. The most evident injuries were found in treatments with lactofen $(23 \%$ at 28 days after application).

In spite of observing negative effects of some mixtures in relation to plant growth (crop canopy and height), there was no situation in which such effects caused plant death once the crop stand was not affected (data not shown). Similarly, when the number of pods per plant and hundred grain mass were compared to their twofold checks for each treatment, no significant differences were observed (data not shown).

Mean yield of soybean was not affected significantly by treatments used in this experiment (Table 4). Hence, we conclude that all treatments used in this experiment were selective to soybean, cultivar CD 214 RR, in the conditions which it was carried out.

\section{Experiment II}

Regarding the first glyphosate application (720 g a.e. ha ${ }^{-1}$ ), soybean was slightly affected by all treatments (Table 5). In contrast, Correia \& Durigan (2007) compared several 
Table 2 - Soil cover by crop canopy, cultivar CD 214 RR, submitted to different sequential treatments with glyphosate, whether isolated or mixed with other herbicides in postemergence, at 15 days after the first application (DAA) and at 3 days after the second application (DASA) (Experiment I). Florai, PR, 2006/2007

\begin{tabular}{|c|c|c|c|c|c|}
\hline \multirow{3}{*}{ Treatment } & \multirow{3}{*}{ Rate $\left(\mathrm{g} \mathrm{ha}^{-1}\right)^{\frac{1}{}}$} & \multirow{2}{*}{\multicolumn{2}{|c|}{$\frac{\% \text { of soil cover (15 DAA) }}{\text { Herbicide }^{2 /}}$}} & \multirow{2}{*}{\multicolumn{2}{|c|}{$\frac{\% \text { of soil cover (3 DASA) }}{\text { Herbicide }^{2 /}}$}} \\
\hline & & & & & \\
\hline & & With & Without & With & Without \\
\hline Gly+cloransulam/gly & $720+30.24 / 480$ & $56.25 \mathrm{a}$ & $60.00 \mathrm{a}$ & $61.26 \mathrm{a}$ & $65.01 \mathrm{a}$ \\
\hline Gly+fomesafen/gly & $720+125 / 480$ & $47.50 \mathrm{~b}$ & $59.38 \mathrm{a}$ & $50.01 \mathrm{~b}$ & $60.76 \mathrm{a}$ \\
\hline Gly+lactofen/gly & $720+72 / 480$ & $52.50 \mathrm{~b}$ & $60.38 \mathrm{a}$ & $51.26 \mathrm{~b}$ & $61.64 \mathrm{a}$ \\
\hline Gly+chlorimuron/gly & $720+12.5 / 480$ & $42.50 \mathrm{~b}$ & $53.88 \mathrm{a}$ & $45.76 \mathrm{~b}$ & $56.26 \mathrm{a}$ \\
\hline Gly+flumiclorac/gly & $720+30 / 480$ & $50.00 \mathrm{a}$ & $55.00 \mathrm{a}$ & $57.26 \mathrm{a}$ & $58.14 \mathrm{a}$ \\
\hline Gly+bentazon/gly & $720+480 / 480$ & $52.50 \mathrm{a}$ & $57.50 \mathrm{a}$ & $55.01 \mathrm{a}$ & $59.14 \mathrm{a}$ \\
\hline Gly+imazethapyr/gly & $720+80 / 480$ & $50.00 \mathrm{~b}$ & $62.50 \mathrm{a}$ & $52.51 \mathrm{~b}$ & $62.01 \mathrm{a}$ \\
\hline Gly/gly & $720 / 480$ & $61.25 \mathrm{a}$ & $59.38 \mathrm{a}$ & $67.51 \mathrm{a}$ & $63.76 \mathrm{a}$ \\
\hline Gly/gly & $960 / 480$ & $60.00 \mathrm{a}$ & $56.25 \mathrm{a}$ & $57.51 \mathrm{a}$ & $60.76 \mathrm{a}$ \\
\hline Gly/gly & $1200 / 480$ & $57.50 \mathrm{a}$ & $56.25 \mathrm{a}$ & $61.26 \mathrm{a}$ & $62.01 \mathrm{a}$ \\
\hline Gly/gly & $960 / 720$ & $61.25 \mathrm{a}$ & $55.63 \mathrm{a}$ & $62.01 \mathrm{a}$ & $61.64 \mathrm{a}$ \\
\hline $\mathrm{CV}(\%)$ & & \multicolumn{2}{|c|}{8.27} & \multicolumn{2}{|c|}{6.49} \\
\hline DMS (Tukey, 5\%) & & \multicolumn{2}{|c|}{6.64} & \multicolumn{2}{|c|}{5.49} \\
\hline
\end{tabular}

For each variable analyzed, means followed by the same letters in the same line (with $\mathrm{x}$ without herbicide) do not differ from each other by Tukey test at $5 \%$ probability.

${ }^{1 /}$ grams of active ingredient or acid equivalent per hectare. ${ }^{2 /}$ Represents treatments which received herbicide application (WITH) and their respective twofold checks which did not receive herbicide treatments. Gly - glyphosate. +: Herbicide tank mixtures. /: Sequential applications.

Table 3 - Average height (cm) of soybean plants at 15 and 90 days after the second application (DASA), cultivar CD 214 RR, submitted to different sequential treatments with glyphosate, whether isolated or mixed with other herbicides in postemergence (Experiment I). Floraí, PR, 2006/2007

\begin{tabular}{|c|c|c|c|c|c|}
\hline \multirow{3}{*}{ Treatment } & \multirow{3}{*}{ Rate $\left(\mathrm{g} \mathrm{ha}^{-1}\right)^{1 /}$} & \multirow{2}{*}{\multicolumn{2}{|c|}{$\frac{\text { Height (15 DASA) }}{\text { Herbicide }^{2 /}}$}} & \multirow{2}{*}{\multicolumn{2}{|c|}{$\frac{\text { Height (90 DASA) }}{\text { Herbicide }^{\underline{2}}}$}} \\
\hline & & & & & \\
\hline & & With & Without & With & Without \\
\hline Gly+cloransulam/gly & $720+30.24 / 480$ & $39.88 \mathrm{a}$ & $40.69 \mathrm{a}$ & $55.83 \mathrm{~b}$ & $62.51 \mathrm{a}$ \\
\hline Gly+fomesafen/gly & $720+125 / 480$ & $34.63 \mathrm{~b}$ & $40.55 \mathrm{a}$ & $50.95 \mathrm{~b}$ & $61.61 \mathrm{a}$ \\
\hline Gly+lactofen/gly & $720+72 / 480$ & $39.30 \mathrm{a}$ & $43.00 \mathrm{a}$ & $56.58 \mathrm{a}$ & $61.66 \mathrm{a}$ \\
\hline Gly+chlorimuron/gly & $720+12.5 / 480$ & $37.98 \mathrm{a}$ & $38.03 \mathrm{a}$ & $49.98 \mathrm{~b}$ & $56.21 \mathrm{a}$ \\
\hline Gly+flumiclorac/gly & $720+30 / 480$ & $40.03 \mathrm{a}$ & $39.18 \mathrm{a}$ & $58.30 \mathrm{a}$ & $59.95 \mathrm{a}$ \\
\hline Gly+bentazon/gly & $720+480 / 480$ & $37.78 \mathrm{a}$ & $39.13 \mathrm{a}$ & $54.48 \mathrm{a}$ & $59.50 \mathrm{a}$ \\
\hline Gly+imazethapyr/gly & $720+80 / 480$ & $37.40 \mathrm{~b}$ & $43.68 \mathrm{a}$ & $56.80 \mathrm{~b}$ & $66.45 \mathrm{a}$ \\
\hline Gly/gly & $720 / 480$ & $42.83 \mathrm{a}$ & $40.41 \mathrm{a}$ & $58.18 \mathrm{a}$ & $60.84 \mathrm{a}$ \\
\hline Gly/gly & $960 / 480$ & $41.75 \mathrm{a}$ & $40.20 \mathrm{a}$ & $60.85 \mathrm{a}$ & $61.38 \mathrm{a}$ \\
\hline Gly/gly & $1200 / 480$ & $41.08 \mathrm{a}$ & $40.21 \mathrm{a}$ & $57.63 \mathrm{a}$ & $61.54 \mathrm{a}$ \\
\hline Gly/gly & $960 / 720$ & $41.95 \mathrm{a}$ & $38.31 \mathrm{a}$ & $59.15 \mathrm{a}$ & $60.13 \mathrm{a}$ \\
\hline $\mathrm{CV}(\%)$ & & \multicolumn{2}{|c|}{7.02} & \multicolumn{2}{|c|}{6.33} \\
\hline DMS (Tukey, 5\%) & & \multicolumn{2}{|c|}{4.04} & \multicolumn{2}{|c|}{5.35} \\
\hline
\end{tabular}

For each variable analyzed, means followed by the same letters in the same line (with $\mathrm{x}$ without herbicide) do not differ from each other by Tukey test at $5 \%$ probability.

${ }^{1 /}$ grams of active ingredient or acid equivalent per hectare. ${ }^{2 /}$ Represents treatments which received herbicide application (WITH) and their respective twofold checks which did not receive herbicide treatments. Gly - glyphosate. +: Herbicide tank mixtures. /: Sequential applications. 
commercial glyphosate formulations and concluded that the herbicides did not cause phytotoxic effects which could be visualized on soybean plants, cultivar CD 214 RR. Procópio et al. (2007) also report that intoxication injuries on RR soybean plants caused by the application of isolated glyphosate were not observed.

Table 4 - Soybean yield $\left(\mathrm{kg} \mathrm{ha}^{-1}\right)$, cultivar CD $214 \mathrm{RR}$, submitted to different sequential treatments with glyphosate, whether isolated or mixed with other herbicides (Experiment I). Floraí, PR, 2006/2007

\begin{tabular}{|c|c|c|c|}
\hline \multirow{3}{*}{ Treatment } & \multirow{3}{*}{ Rate $\left(\mathrm{g} \mathrm{ha}^{-1}\right)^{1 /}$} & \multirow{2}{*}{\multicolumn{2}{|c|}{$\frac{\text { Grain Yield }\left(\mathrm{kg} \mathrm{ha}^{-1}\right)}{\text { Herbicide }^{\underline{2}}}$}} \\
\hline & & & \\
\hline & & With & Withou \\
\hline Glyphosate+cloransulam/glyphosate & $720+30.24 / 480$ & $3055.02 \mathrm{a}$ & $3023.69 \mathrm{a}$ \\
\hline Glyphosate+fomesafen/glyphosate & $720+125 / 480$ & $2855.07 \mathrm{a}$ & $2906.93 \mathrm{a}$ \\
\hline Glyphosate+lactofen/glyphosate & $720+72 / 480$ & $2807.94 \mathrm{a}$ & $2763.03 \mathrm{a}$ \\
\hline Glyphosate+chlorimuron/glyphosate & $720+12.5 / 480$ & $2840.17 \mathrm{a}$ & $2873.73 \mathrm{a}$ \\
\hline Glyphosate+flumiclorac/glyphosate & $720+30 / 480$ & $2727.18 \mathrm{a}$ & $2713.40 \mathrm{a}$ \\
\hline Glyphosate+bentazon/glyphosate & $720+480 / 480$ & $2816.07 \mathrm{a}$ & $2814.91 \mathrm{a}$ \\
\hline Glyphosate+imazethapyr/glyphosate & $720+80 / 480$ & $2723.94 \mathrm{a}$ & $2779.95 \mathrm{a}$ \\
\hline Glyphosate/glyphosate & $720 / 480$ & $2935.98 \mathrm{a}$ & $3009.10 \mathrm{a}$ \\
\hline Glyphosate/glyphosate & $960 / 480$ & $2744.79 \mathrm{a}$ & $2641.53 \mathrm{a}$ \\
\hline Glyphosate/glyphosate & $1200 / 480$ & $2901.17 \mathrm{a}$ & $2797.59 \mathrm{a}$ \\
\hline Glyphosate/glyphosate & $960 / 720$ & $2855.59 \mathrm{a}$ & $2753.23 \mathrm{a}$ \\
\hline $\mathrm{CV}(\%)$ & & \multicolumn{2}{|c|}{5.57} \\
\hline DMS (Tukey, 5 \%) & & \multicolumn{2}{|c|}{227.21} \\
\hline
\end{tabular}

For each variable analyzed, means followed by the same letters in the same line (with $\mathrm{x}$ without herbicide) do not differ from each other by Tukey test at $5 \%$ probability.

${ }^{1 /}$ grams of active ingredient or acid equivalent per hectare. ${ }^{2 /}$ Represents treatments which received herbicide application (WITH) and their respective twofold checks which did not receive herbicide treatments. +: Herbicide tank mixtures. /: Sequential applications.

Table 5 - Mean soybean injury (visual scale, \%), cultivar CD 214 RR, submitted to different sequential treatments with glyphosate, whether isolated or mixed with other herbicides (Experiment II). Floraí, PR, 2006/2007

\begin{tabular}{|c|c|c|c|c|}
\hline \multirow{3}{*}{ Treatment } & \multirow{3}{*}{ Rate $\left(\mathrm{g} \mathrm{ha}^{-1}\right)^{\frac{1}{1}}$} & \multicolumn{3}{|c|}{ Soybean injury $(\%)$} \\
\hline & & \multicolumn{2}{|c|}{$1^{\text {st }}$ application } & \multirow{2}{*}{$\frac{2^{\text {nd }} \text { application }}{3 \text { DASA }}$} \\
\hline & & 3 DAA & 7 DAA & \\
\hline Glyphosate/glyphosate+cloransulam & $720 / 480+30.24$ & 20.0 & 20.0 & 31.3 \\
\hline Glyphosate/glyphosate+fomesafen & $720 / 480+125$ & 20.0 & 20.0 & 35.0 \\
\hline Glyphosate/glyphosate+lactofen & $720 / 480+72$ & 20.0 & 20.0 & 68.8 \\
\hline Glyphosate/glyphosate+chlorimuron & $720 / 480+12.5$ & 20.0 & 20.0 & 52.5 \\
\hline Glyphosate/glyphosate+flumiclorac & $720 / 480+30$ & 20.0 & 20.0 & 42.5 \\
\hline Glyphosate/glyphosate+bentazon & $720 / 480+480$ & 20.0 & 20.0 & 26.3 \\
\hline Glyphosate/glyphosate+imazethapyr & $720 / 480+80$ & 20.0 & 20.0 & 32.5 \\
\hline Glyphosate/glyphosate & $720 / 480$ & 20.0 & 20.0 & 17.5 \\
\hline Glyphosate/glyphosate & $720 / 720$ & 20.0 & 20.0 & 21.3 \\
\hline Glyphosate/glyphosate & $720 / 960$ & 20.0 & 20.0 & 26.3 \\
\hline Glyphosate/glyphosate & $720 / 1200$ & 20.0 & 20.0 & 27.5 \\
\hline
\end{tabular}

1/ grams of active ingredient or acid equivalent per hectare. DAA: days after application; DASA = days after second application. $(\%)$ : $0 \%=$ no injuries, $100 \%=$ plant death. +: Herbicide tank mixtures. /: Sequential applications. 
Symptoms observed in evaluations were slight chlorosis on older leaves, and distortion and intense chlorosis on younger leaves. However, these symptoms were not again observed during evaluation carried out at 15 DAA.

After the second application, treatments containing mixtures caused more evident injuries on plants with visual symptoms similar to those described in experiment I.

The glyphosate+lactofen mixture caused the most severe visual injuries in the soybean trifoliolate leaves $(68.8 \%)$. On the other hand, there was a slight increase in injury level for the sequential application of isolated glyphosate ( $\geq 960$ g a.e. ha $\left.{ }^{1}\right)$, probably due to the effects of this herbicide on macro and micronutrients contents, photosynthetic rate, and chlorophyll content (Zobiole et al., 2010a, $\mathrm{b}, \mathrm{c}, \mathrm{d})$.

Visual evaluations of soil cover by crop canopy were carried out only after the second application at 3 and 15 DASA (Table 6). With regards to crop canopy, it is possible to observe that when treatments were compared to their respective checks at 3 DASA, only sequential applications of glyphosate (720/720 and 720/ $1.200 \mathrm{~g}$ a.e. ha $\mathrm{h}^{-1}$ ) and glyphosate/bentazon+ glyphosate did not present significant reductions in canopy development. All other treatments were significantly affected when compared to their respective checks. The largest differences were observed for the treatments glyphosate/lactofen+glyphosate, glyphosate/chlorimuron-ethyl+glyphosate, and glyphosate/glyphosate $(720 / 480$ g a.e. ha-1), $(22.5 \%, 21.88 \%$, and $18.75 \%$, respectively). Ferreira Neto et al. (2009) observed that glyphosate in mixture with diclosulam, clorosulam-methyl, flumioxazin and $\mathrm{S}$-metolachlor did not affect soybean grain yield. Nevertheless, plant growth and crop canopy were affected by mixtures of glyphosate with flumioxazin or S-metolachlor.

In relation to results obtained at 15 DASA, it is possible to verify that the effects of treatments with lactofen and chlorimuronethyl persisted, and crop canopy which received such treatments still presented results significantly inferior to those observed for its checks at this period. Soybean plants which received the other treatments recovered at 15 DASA and did not present significant differences in relation to their checks.

Regarding height at 15 (DASA), treatments with mixtures of glyphosate with chlorimuronethyl, imazethapyr and sequential applications of glyphosate at $720 / 480$ g a.e. ha ${ }^{-1}$ or $720 /$ $960 \mathrm{~g}$ a.e. ha ${ }^{-1}$ promoted significant reductions in soybean height whereas the other treatments did not cause significant negative effects for this variable (Table 7). Procópio et al. (2007) also observed reductions in height and dry mass of soybean shoots when they were treated with glyphosate+imazethapyr at 28 days after soybean emergence.

When height of soybean plants treated with herbicides was compared to their checks without herbicide at 90 DASA, all treatments affected soybean promoting height reduction ranging from 5.85 to $16.35 \mathrm{~cm}$. These results suggest that applications of mixtures containing glyphosate or isolated glyphosate at late stages of crop vegetative development may cause significant reductions in plant height, because there was not enough time for the crop to recover from injuries and reestablish vegetative growth, which might consequently reflect in lower yield (Table 7).

No treatment evaluated in this experiment reduced soybean plant stand and the average number of pods per plant when compared to their twofold checks, which means that although they did cause negative effects in some characteristics evaluated, such effects did not cause plant death in any case (data not shown).

With regards to effect of treatments on the average hundred grain weight, treatments with cloransulam and lactofen significantly affected this yield component when compared to their respective checks. The other treatments did not affect the hundred grain weight (Table 8).

Mean soybean yield was affected by treatments containing lactofen or bentazon in mixture with glyphosate. The lactofen treatment presented reduction of $344 \mathrm{~kg} \mathrm{ha}^{-1}$ in relation to its check, while the bentazon treatment reduced $203 \mathrm{~kg} \mathrm{ha}^{-1}$ when compared to its check (Table 8). 
Table 6 - Soil cover by soybean canopy, cultivar CD 214 RR, submitted to different sequential treatments with glyphosate, whether isolated or mixed with other herbicides in postemergence, at 3 and 15 days after the second application (DASA) (Experiment II). Floraí, PR, 2006/2007

\begin{tabular}{|c|c|c|c|c|c|}
\hline \multirow{3}{*}{ Treatment } & \multirow{3}{*}{ Rate $\left(\mathrm{g} \mathrm{ha}^{-1}\right)^{\frac{1}{}}$} & \multirow{2}{*}{\multicolumn{2}{|c|}{$\frac{\% \text { of soil cover (3 DASA) }}{\text { Herbicide }^{-/}}$}} & \multirow{2}{*}{\multicolumn{2}{|c|}{$\frac{\% \text { of soil cover (15 DASA) }}{\text { Herbicide }^{\underline{2} /}}$}} \\
\hline & & & & & \\
\hline & & With & Without & With & Without \\
\hline Gly/gly+cloransulam & $720 / 480+30.24$ & $65.00 \mathrm{~b}$ & $73.75 \mathrm{a}$ & $95.75 \mathrm{a}$ & $93.75 \mathrm{a}$ \\
\hline Gly/gly+fomesafen & $720 / 480+125$ & $51.25 \mathrm{~b}$ & $61.25 \mathrm{a}$ & $88.75 \mathrm{a}$ & $92.88 \mathrm{a}$ \\
\hline Gly/gly+lactofen & $720 / 480+72$ & $46.25 \mathrm{~b}$ & $68.75 \mathrm{a}$ & $79.25 \mathrm{~b}$ & $92.75 \mathrm{a}$ \\
\hline Gly/gly+chlorimuron & $720 / 480+12.5$ & $47.50 \mathrm{~b}$ & $69.38 \mathrm{a}$ & $91.00 \mathrm{a}$ & $95.88 \mathrm{a}$ \\
\hline Gly/gly+flumiclorac & $720 / 480+30$ & $51.25 \mathrm{~b}$ & $59.38 \mathrm{a}$ & $84.00 \mathrm{a}$ & $86.38 \mathrm{a}$ \\
\hline Gly/gly+bentazon & $720 / 480+480$ & $67.50 \mathrm{a}$ & $72.50 \mathrm{a}$ & $94.25 \mathrm{a}$ & $92.50 \mathrm{a}$ \\
\hline Gly/gly+imazethapyr & $720 / 480+80$ & $47.50 \mathrm{~b}$ & $63.13 \mathrm{a}$ & $76.25 \mathrm{~b}$ & $88.25 \mathrm{a}$ \\
\hline Gly/gly & $720 / 480$ & $55.00 \mathrm{~b}$ & $73.75 \mathrm{a}$ & $92.75 \mathrm{a}$ & $95.38 \mathrm{a}$ \\
\hline Gly/gly & $720 / 720$ & $66.25 \mathrm{a}$ & $73.13 \mathrm{a}$ & $95.00 \mathrm{a}$ & $95.00 \mathrm{a}$ \\
\hline Gly/gly & $720 / 960$ & $62.50 \mathrm{~b}$ & $70.63 \mathrm{a}$ & $93.50 \mathrm{a}$ & $93.75 \mathrm{a}$ \\
\hline Gly/gly & $720 / 1200$ & $58.75 \mathrm{a}$ & $63.75 \mathrm{a}$ & $90.50 \mathrm{a}$ & $91.63 \mathrm{a}$ \\
\hline $\mathrm{CV}(\%)$ & & \multicolumn{2}{|c|}{8.34} & \multicolumn{2}{|c|}{4.70} \\
\hline DMS (Tukey, 5\%) & & \multicolumn{2}{|c|}{7.46} & \multicolumn{2}{|c|}{6.15} \\
\hline
\end{tabular}

For each variable analyzed, means followed by the same letters in the same line (with $\mathrm{x}$ without herbicide) do not differ from each other by Tukey test at $5 \%$ probability.

${ }^{1 /}$ grams of active ingredient or acid equivalent per hectare. ${ }^{2 /}$ Represents treatments which received herbicide application (WITH) and their respective twofold checks which did not receive herbicide treatments. Gly - glyphosate. +: Herbicide tank mixtures. /: Sequential applications.

Table 7 - Average height $(\mathrm{cm})$ of soybean plants at 15 and 90 days after the second application (DASA), cultivar CD 214 RR, submitted to different sequential treatments with glyphosate, whether isolated or mixed with other herbicides in postemergence (Experiment II). Floraí, PR, 2006/2007

\begin{tabular}{|c|c|c|c|c|c|}
\hline \multirow{3}{*}{ Treatment } & \multirow{3}{*}{ Rate $\left(\mathrm{g} \mathrm{ha}^{-1}\right)^{1 /}$} & \multirow{2}{*}{\multicolumn{2}{|c|}{$\frac{\text { Height (15 DASA) }}{\text { Herbicide }^{\underline{2} /}}$}} & \multirow{2}{*}{\multicolumn{2}{|c|}{$\begin{array}{c}\text { Height (90 DASA) } \\
\text { Herbicide }^{2 /}\end{array}$}} \\
\hline & & & & & \\
\hline & & With & Without & With & Withou \\
\hline Gly/gly+cloransulam & $720 / 480+30.24$ & $41.30 \mathrm{a}$ & $40.86 \mathrm{a}$ & $53.78 \mathrm{~b}$ & $62.74 \mathrm{a}$ \\
\hline Gly/gly+fomesafen & $720 / 480+125$ & $32.53 \mathrm{a}$ & $37.26 \mathrm{a}$ & $46.23 \mathrm{~b}$ & $58.63 \mathrm{a}$ \\
\hline Gly/gly+lactofen & $720 / 480+72$ & $33.55 \mathrm{a}$ & $37.21 \mathrm{a}$ & $44.85 \mathrm{~b}$ & $59.88 \mathrm{a}$ \\
\hline Gly/gly+chlorimuron & $720 / 480+12.5$ & $32.65 \mathrm{~b}$ & $41.33 \mathrm{a}$ & $47.68 \mathrm{~b}$ & $62.54 \mathrm{a}$ \\
\hline Gly/gly+flumiclorac & $720 / 480+30$ & $33.20 \mathrm{a}$ & $34.46 \mathrm{a}$ & $47.50 \mathrm{~b}$ & $55.08 \mathrm{a}$ \\
\hline Gly/gly+bentazon & $720 / 480+480$ & $39.20 \mathrm{a}$ & $40.58 \mathrm{a}$ & $57.50 \mathrm{~b}$ & $63.35 \mathrm{a}$ \\
\hline Gly/gly+imazethapyr & $720 / 480+80$ & $30.88 \mathrm{~b}$ & $37.21 \mathrm{a}$ & $44.05 \mathrm{~b}$ & $56.59 \mathrm{a}$ \\
\hline Gly/gly & $720 / 480$ & $36.08 \mathrm{~b}$ & $41.20 \mathrm{a}$ & $46.78 \mathrm{~b}$ & $63.13 \mathrm{a}$ \\
\hline Gly/gly & $720 / 720$ & $40.45 \mathrm{a}$ & $43.23 \mathrm{a}$ & $51.48 \mathrm{~b}$ & $64.39 \mathrm{a}$ \\
\hline Gly/gly & $720 / 960$ & $33.13 \mathrm{~b}$ & $39.53 \mathrm{a}$ & $46.58 \mathrm{~b}$ & $61.84 \mathrm{a}$ \\
\hline Gly/gly & $720 / 1200$ & $35.83 \mathrm{a}$ & $35.84 \mathrm{a}$ & $50.68 \mathrm{~b}$ & $57.61 \mathrm{a}$ \\
\hline $\mathrm{CV}(\%)$ & & \multicolumn{2}{|c|}{9.33} & \multicolumn{2}{|c|}{6.65} \\
\hline DMS (Tukey, $5 \%$ ) & & \multicolumn{2}{|c|}{4.99} & \multicolumn{2}{|c|}{5.24} \\
\hline
\end{tabular}

For each variable analyzed, means followed by the same letters in the same line (with $\mathrm{x}$ without herbicide) do not differ from each other by Tukey test at $5 \%$ probability.

1/ grams of active ingredient or acid equivalent per hectare. ${ }^{2 /}$ Represents treatments which received herbicide application (WITH) and their respective twofold checks which did not receive herbicide treatments. Gly - glyphosate. +: Herbicide tank mixtures. /: Sequential applications. 
Table 8 - Hundred grain mass (g) and yield ( $\left.\mathrm{kg} \mathrm{ha}^{-1}\right)$ of soybean, cultivar CD $214 \mathrm{RR}$, submitted to different sequential treatments with glyphosate, whether isolated or mixed with other herbicides in postemergence (Experiment II). Floraí, PR, 2006/2007

\begin{tabular}{|c|c|c|c|c|c|}
\hline \multirow{3}{*}{ Treatment } & \multirow{3}{*}{ Rate $\left(\mathrm{g} \mathrm{ha}^{-1}\right)^{\frac{1}{}}$} & \multicolumn{2}{|c|}{ Hundred grain mass (g) } & \multicolumn{2}{|c|}{ Grain Yield $\left(\mathrm{kg} \mathrm{ha}^{-1}\right)$} \\
\hline & & \multicolumn{2}{|c|}{ Herbicide $^{2 /}$} & \multicolumn{2}{|c|}{ Herbicide $^{2 /}$} \\
\hline & & With & Without & With & Without \\
\hline Gly/gly+cloransulam & $720 / 480+30.24$ & $12.24 \mathrm{~b}$ & $12.81 \mathrm{a}$ & $2934.09 \mathrm{a}$ & $2927.13 \mathrm{a}$ \\
\hline Gly/gly+fomesafen & $720 / 480+125$ & $12.55 \mathrm{a}$ & $12.55 \mathrm{a}$ & $2846.93 \mathrm{a}$ & $2852.31 \mathrm{a}$ \\
\hline Gly/gly+lactofen & $720 / 480+72$ & $12.05 \mathrm{~b}$ & $12.68 \mathrm{a}$ & $2541.00 \mathrm{~b}$ & $2885.09 \mathrm{a}$ \\
\hline Gly/gly+chlorimuron & $720 / 480+12.5$ & $12.40 \mathrm{a}$ & $12.42 \mathrm{a}$ & $2676.44 \mathrm{a}$ & $2809.28 \mathrm{a}$ \\
\hline Gly/gly+flumiclorac & $720 / 480+30$ & $12.37 \mathrm{a}$ & $12.57 \mathrm{a}$ & $2613.21 \mathrm{a}$ & $2707.46 \mathrm{a}$ \\
\hline Gly/gly+bentazon & $720 / 480+480$ & $12.44 \mathrm{a}$ & $12.61 \mathrm{a}$ & $2685.91 \mathrm{~b}$ & $2889.10 \mathrm{a}$ \\
\hline Gly/gly+imazethapyr & $720 / 480+80$ & $12.91 \mathrm{a}$ & $12.61 \mathrm{a}$ & $2795.20 \mathrm{a}$ & $2864.47 \mathrm{a}$ \\
\hline Gly/gly & $720 / 480$ & $12.48 \mathrm{a}$ & $12.59 \mathrm{a}$ & $2883.77 \mathrm{a}$ & $2905.89 \mathrm{a}$ \\
\hline Gly/gly & $720 / 720$ & $12.62 \mathrm{a}$ & $12.69 \mathrm{a}$ & $2941.82 \mathrm{a}$ & $2922.07 \mathrm{a}$ \\
\hline Gly/gly & $720 / 960$ & $12.78 \mathrm{a}$ & $12.81 \mathrm{a}$ & $2890.41 \mathrm{a}$ & $2890.27 \mathrm{a}$ \\
\hline Gly/gly & $720 / 1200$ & $12.52 \mathrm{a}$ & $12.50 \mathrm{a}$ & $2732.18 \mathrm{a}$ & $2733.88 \mathrm{a}$ \\
\hline $\mathrm{CV}(\%)$ & & \multicolumn{2}{|c|}{2.37} & \multicolumn{2}{|c|}{4.45} \\
\hline DMS (Tukey, 5\%) & & \multicolumn{2}{|c|}{0.43} & \multicolumn{2}{|c|}{180.31} \\
\hline
\end{tabular}

For each variable analyzed, means followed by the same letters in the same line (with $\mathrm{x}$ without herbicide) do not differ from each other by Tukey test at $5 \%$ probability.

1/ grams of active ingredient or acid equivalent per hectare. ${ }^{2 /}$ Represents treatments which received herbicide application (WITH) and their respective twofold checks which did not receive herbicide treatments. Gly - glyphosate. +: Herbicide tank mixtures. /: Sequential applications.

Soybean yield reduction observed for the treatment glyphosate+lactofen suggests that injuries caused by these herbicides in crop vegetative development such as severe visual phytointoxication, delay in canopy development and height reduction of about $15 \mathrm{~cm}$ might have led the plants to unsatisfactorily supply their reproductive needs, and consequently presenting lighter grains and lower yield.

With regards to the glyphosate+bentazon treatment, results indicate that reduction in height at 90 DASA was the only variable affected significantly besides yield, and also that visual injuries are not high enough to justify the difference in yield. However, although individual effects on yield components (stand, number of pods, crop canopy and hundred grain mass) were not affected, when these slight individual effects are added up they resulted in grain yield reduction.

Hence, we suggest that these treatments (glyphosate+lactofen and glyphosate+bentazon) did not show selectivity to soybean, cultivar CD $214 \mathrm{RR}$, for the conditions in which the experiment was carried out.
Results obtained in these experiments show that applications of glyphosate mixtures with other herbicides present selectivity to RR soybean when applied at younger stages (experiment I) whereas later applications of mixtures might cause yield losses, especially when glyphosate is mixed with lactofen and bentazon (experiment II). Although sequential applications of isolated glyphosate present phytointoxication symptoms, it was observed that they do not cause yield reduction. Glyphosate applications in mixture with other herbicides in postemergence may promote slower crop growth. However, such effects are not enough to promote stand reduction of soybean plants, cultivar CD 214 RR.

\section{LITERATURE CITED}

CORREIA, N. M.; DURIGAN, J. C. Seletividade de diferentes herbicidas à base de glyphosate a soja RR. Planta Daninha, v. 25, n. 2, p. 375-379, 2007.

ELLIS, J. M.; GRIFFIN, J. L. Glyphosate and broadleaf herbicide mixtures for soybean (Glycine max). Weed Technol., v. 17, n. 1, p. 21-27, 2003. 
ELMORE, R. W. et al. Glyphosate-resistant soybean cultivar response to glyphosate. Agron. J., v. 93, n. 2, p. 404-407, 2001.

FAGLIARI, J. R.; OLIVEIRA JR., R. S.; CONSTANTIN, J. Métodos de avaliação da seletividade de herbicidas para a cultura da cana-de-açúcar (Saccharum spp.). Acta Sci., v. 23, n. 5, p. 1229-1234, 2001

GONZINI, L. C.; HART, S. E.; WAX, L. M. Herbicide combinations for weed management in glyphosate-resistant soybean (Glycine max). Weed Technol., v. 13, n. 2, p. $354-360,1999$.

GREY, T. L.; RAYMER, P. Sicklepod (Senna obtusifolia) and red morningglory (Ipomea coccinea) control in glyphosateresistant soybean with narrow rows and postemergence herbicide mixtures. Weed Technol., v. 16, n. 3, p. 669-674, 2002.

JAREMTCHUK, C. C. et al. Efeito de sistemas de manejo sobre a velocidade de dessecação, infestação inicial de plantas daninhas e desenvolvimento e produtividade de soja. Acta Sci. Agron., v. 30, n. 4, p. 449-455, 2008.

LICH, J. M.; RENNER, K. A.; PENNER, D. Interaction of glyphosate with postemergence soybean (Glycine max) herbicides. Weed Sci., v. 45, n. 1, p. 12-21, 1997.

MESCHEDE, D. K. et al. Período anterior à interferência de plantas daninhas em soja: estudo de caso com baixo estande e testemunhas duplas. Planta Daninha, v. 22, n. 2 , p. 239-246, 2004.

FERREIRA NETO, M.E. et al. Seletividade de herbicidas pós-emergentes aplicados na soja geneticamente modificada. Planta Daninha, v. 27, n. 2, p. $345-352,2009$.
NORRIS, J. L.; SHAW, D. R.; SNIPES, C. E. Weed control from herbicide combinations with three formulations of glyphosate. Weed Technol., v. 15, n. 3, p. 552-558, 2001.

NORSWORTHY, J. K. Tolerance of a glyphosate-resistant soybean to late-season glyphosate applications. Weed Technol., v. 18, n. 2, p. 454-457, 2004.

PROCÓPIO, S. O. et al. Utilização de chlorimuron-ethyl e imazethapyr na cultura da soja Roundup Ready ${ }^{\circledR}$. Planta Daninha, v. 25, n. 2, p. 365-373, 2007.

SILVA, A. F. et al. Período anterior à interferência na cultura da soja-RR em condições de baixa, média e alta infestação.

Planta Daninha, v. 27, n. 1, p. 57-66, 2009.

SOCIEDADE BRASILEIRA DA CIÊNCIA DAS PLANTAS DANINHAS - SBCPD. Procedimentos para instalação, avaliação e análise de experimentos com herbicidas. Londrina: 1995. $42 \mathrm{p}$.

ZOBIOLE, L. H. S. et al. Glyphosate reduces shoot concentrations of mineral nutrients in glyphosate-resistant soybeans. Plant Soil, v. 328, n. 1, p. 57-69, 2010a.

ZOBIOLE, L. H. S. et al. Water use efficiency and photosynthesis of glyphosate-resistant soybean as affected by glyphosate. Pestic. Biochem. Physiol., v. 97, n. 3, p. $182-193,2010$ b.

ZOBIOLE, L. H. S. et al. Nutrient accumulation and photosynthesis in glyphosate-resistant soybeans is reduced under glyphosate use. J. Plant Nutr., v. 33, n. 12, p. $1860-1873,2010 \mathrm{c}$

ZOBIOLE, L. H. S. et al. Glyphosate affects seed composition in glyphosate-resistant soybean. J. Agric. Food Chem., v. 58, n. 7, p. 4517-4522, 2010 d. 